\title{
Vulnerabilities of Indonesia's Extractive Industry to Illicit Financial Flows
}

\section{JIMMY DANIEL BERLIANTO OLEY, YERIKHO SETYO ADI}

The SMERU Research Institute

Universitas Gadjah Mada

jimmyberlianto@gmail.com

adi.yerikho@gmail.com

p-ISSN 2477-118X

e-ISSN 2615-7977

\section{A B S T R A C T}

This article aims to explain the vulnerabilities of Indonesia's extractive industry governance to the illicit financial flows. Earlier studies figured out that the company in extractive industry has been found to be one of the prominent actors of illicit financial flows. In the case of Indonesia during the period of 2004-2013, the data of Global Financial Integrity (GFI) illustrated that Indonesia is among the top 10 developing countries - which have the highest value of illicit financial flows. This article seeks to explain the nature of illicit financial flows on extractive industry, the causation of why Indonesia's extractive industry is prone to the illicit financial flows, and finally the recommendation in addressing the issue. In doing so, the researchers conduct the qualitative desk research on explanatory methodology. The result explains that at least there are two natures 
of illicit financial flows on extractive industry, the behavior of rentseeking and the dynamics of commodity prices. This article also found out that there are three main sources of regulatory vulnerability which may accommodate the rent-seeking behavior - which directly and indirectly influence the illicit financial flow, which are the different sets of revenue data, arm's length measurement within the vulnerable enforcement, and regarding the cost recovery scheme. Other than that, the multi-level governance context shown by the decentralization policy of natural resources in Indonesia widens the loopholes of Indonesia's extractive industry illicit financial flows.

Keywords: extractive industry, illicit financial flows, governance, rent-seeking

\section{A B S T R A K}

Artikel ini bertujuan untuk menjelaskan kerentanan tata kelola industri ekstraktif di Indonesia terhadap illicit financial flows. Penelitian sebelumnya mengemukakan bahwa industri ekstraktif adalah salah satu aktor utama dalam illicit financial flows. Dalam kasus Indonesia, pada tahun 2004-2013 Global Financial Integrity (GFI) memasukkan Indonesia dalam 10 negara berkembang dengan nilai illicit financial flows tertinggi. Artikel ini mencoba menjelaskan hakikat illicit financial flows pada industri ekstraktif, penyebab industri ekstraktif di Indonesia rentan terhadap illicit financial flows, dan rekomendasi dalam menyelesaikan permasalahan ini. Setidaknya terdapat dua hakikat illicit financial flows pada industri ekstraktif, dipicu oleh perilaku rent-seeking dan dinamika harga komoditas. Artikel ini juga menemukan bahwa ada tiga sumber peraturan yang rentan untuk mengakomodasi perilaku rent-seeking yang secara langsung maupun tidak langsung mempengaruhi illicit financial flows, yaitu pengumpulan data pendapatan yang berbeda, arm's length measurement pada penegakan yang rentan, dan skema cost recovery. Selain itu konteks multi-level governance yang ditunjukkan oleh kebijakan desentralisasi sumber daya alam di Indonesia juga memperlebar celah bagi illicit financial flows.

Kata kunci: industri ekstraktif, illicit financial flows, tata kelola, pemburu rente 


\section{A. INTRODUCTION}

Illicit financial flows is an issue in contemporary democracy and financial system which has not received the spotlight it deserved. Illicit financial flows can be understood in its various spectrum, which include tax avoidance and evasion, illegal flows of capital, and other kinds of covert flows of capital in the gray area between legal and illegal, as the scope of the issue is still much debated. Illicit financial flows in this article is understood as illegal movements of money or capital from one country to another - such financial flows are considered to be illicit when the funds are illegally earned, transferred, or utilized. ${ }^{1}$ One way of looking into illicit financial flows is by elucidating how it came to be and what relevance it brings into nowadays problems of governance, corruption, and democratic system. In this regard, illicit financial flows would be focused on its offshoring of covert and opaque capital flows spectrum in terms of its avoidance and evasive nature which will be further contextualized below.

Illicit financial flows cannot be separated from the dynamics of globalization and the existence of tax havens. Offshore finance itself can be traced back to the implementation of the Bretton Wood System which regulated the fixed exchange rate with the United States (US) dollar as the international standard. To avoid US regulation on interest limits and reserves, the banks in Europe used dollars outside of US - which then called Eurodollars - which bred the transaction dichotomy between onshore and offshore label to indicate the transactions that are happening inside and outside of a jurisdiction. ${ }^{2}$ The offshore finance dynamics made possible the onset of illicit financial flows through tax avoidance and evasion which is pioneered in Switzerland. The needs to secure financial wealth inspired Banks to develop financial wealth management as one of its activity which also offered a service of avoiding declaring the interests and dividends earned ${ }^{3}$, thus leading to the covert nature of financial flows due to the

1 Matthew Salomon - Joseph Spanjers, Illicit Financial Flows to and from Developing Countries: 2005-2014 (Washington, DC: Global Financial Integrity, 2017), p. 14 .

2 O. Bullough, "The Dark Side of Globalization", Journal of Democracy, Vol. 29 No. 1, January 2018, p. 30.

3 Gabriel Zucman, The Hidden Wealth of Nations: The Scourge of Tax Havens (Chicago: The University of Chicago Press, 2015), p.12. 
lack of communication and regulation between the establishment and the origin country.

The mechanization of the illicit flows is continued to be developed within the international financial system which is no longer done only by individuals in securing wealth, but also by companies in order to secure its revenue from taxes. As a Tax Haven, Switzerland has been followed by other countries, such as Singapore and the Bahamas. The significance of this continuing trend can be seen by looking into the data of the capital flow itself.

In terms of total financial wealth of households globally, up until 2014 the value of illicit financial capital is approximately $\$ 7.6$ trillion or $8 \%$ out of $\$ 95.5$ trillion. ${ }^{4}$ In other words, there are approximately $\$ 7.6$ trillion of undocumented wealth in terms of its origin countries' interests. Looking into the data of the overall capital flows, Global Financial Integrity (GFI) produced reports that estimated the volume of illicit flows that ranged between $\$ 2$ trillion to $\$ 3.5$ trillion with average annual growth rate between 8.5\% and 10.4\% during 20052014 period. ${ }^{5}$ The data analysis especially tried to show the flows in regards to the illicit outflows and inflows between developing and developed countries. The number shows significance for developing countries which estimated to have $\$ 620$ billion worth of illicit financial flows value that is approximately to be between $13.8 \%$ and $24 \%$ of its total trade with Asia regions amounted the highest value of the illicit outflows.

In terms of sources, companies in extractive industries have been found to be one of the prominent actors of the illicit financial activities. The extractive industries are prone to illicit financial flows arguably due to its nature of rent-seeking and the dynamics of its commodity price. William produced an empirical analysis in order to look at the issue's foundation; on the relations between natural resources and transparency, and found that natural resources have a negative impact on transparency at $1 \%$ statistical significance by factoring in various transparency and types of resource variables. ${ }^{6}$ In this regard, The Anti-Corruption Resource Centre argued that there

4 Ibid., p. 35 .

5 Salomon - Spanjers, Op. cit., p.2.

6 A. Williams, "Shining a Light on the Resource Curse: An Empirical Analysis of the Relationship between Natural Resources, Transparency, and Economic Growth”, World Development, Vol. 39, No. 4, 2011, p. 495. 
are three main sources of illicit financial flows from the extractive sector, which are corruption, illegal exploitation, and tax evasion.7 The three sources are not mutually exclusive as they are able to be intertwined. This issue is especially crucial for resource-rich countries which have been seeing themselves not reaping full benefits from its extractive commodities, such as oil, gas, and mining.

Indonesia as one of the countries that have abundance extractive commodities also struggle with the same problems. During the period of 2004-2013, GFI's database illustrates that Indonesia is among the top 10 countries - among the developing countries to be precise which have the highest value of illicit financial flows with $\$ 180.710$ million. ${ }^{8}$ Even though in terms of ranks it shows a decline, which is from $8^{\text {th }}$ in the 2014 report, there is only a slight difference in terms of its average value. Publish What You Pay (PWYP) Indonesia found that the mining sector accounted for $10.5 \%$ of total illicit financial flows in Indonesia with IDR 23.89 trillion which is equal to $11.7 \%$ of revised state budget (APBN-P) ${ }^{9}$ It is similar with the overall calculation which estimates that the annual illicit outflow from Indonesia is equivalent to around $10 \%$ of the state budget (ABPN)..$^{10}$

There are efforts that have been made, be it globally or by Indonesia, to tackle the opaque web of illicit financial flows, however the problem is still prominent up until now. Between 2003-2014 period, the illicit financial flows in oil, gas, mineral, and coal sectors in Indonesia show steady growth of around $8.53 \%$ which is two times bigger than the national growth rate in the same period. ${ }^{11}$

These issues bring the researchers to the questions of why the extractive industries in Indonesia are vulnerable to the illicit financial flows and how to respond in order to tackle the issue in the future. In other words, why does the problem persist and how to stop

7 P. Le Billon, "Extractive Sectors and Illicit Financial Flows: What Role for Revenue Governance Initiatives?”, U4 Issue, No. 13, October 2011, p. 4.

8 It also shows that the top 10 countries are dominated by considerably resource-rich countries, such as Russia, China, and Nigeria. Dev Kar - Joseph Spanjers, Illicit Financial Flows to and from Developing Countries: 2004-2013 (Washington, DC: Global Financial Integrity, 2015), p. 8.

9 Wiko Saputra - Maryati Abdullah,, Illicit Financial Flows and Tax Crime in Mining Sector (Brief Note) (Jakarta: Publish What You Pay Indonesia, 2015), p.1.

10 Prakarsa, Calculating Illicit Financial Flows to and from Indonesia: a Trade Data Analysis, 2001-2014 (Jakarta: Perkumpulan Prakarsa, 2016), p.29. 
the chain of the illicit financial flows. The structure of the paper is divided into four main sections: (1) the introduction highlights the historical development of the illicit financial flows and the overall data of the flows globally and in Indonesia, (2) the nature of why the illicit financial flows, (3) the causation analysis of the vulnerability of Indonesia extractive industries to illicit financial flows, and (4) the recommendations on how to respond to the issues based on the findings and the conclusion.

\section{B.ANALYSIS}

\section{Nature Of Illicit Financial Flows On Extractive Industries In Indonesia}

As mentioned earlier, the extractive industries are prone to the illicit financial flows at least because of the two main natures, the rentseeking and the dynamics of the commodity prices. The rent-seeking, according to the public-choice theory is simply defined as the effort to secure the profit through the political process rather than market process of exchange. ${ }^{12}$ Many have seen the close relations between the rent-seeking and the corruption. Some also use these two terms interchangeably since both of it might cause the form of social loss. From the study of Tullock (1967) about the rent-seeking, at least there are two core ideas that might be applicable in understanding the rent-seeking. The first one, a contestable rent induces the rentseeking activities aimed at capturing the rent. These activities involve unproductive use of real resources and cause of the social loss. The second one, the rent-seeking costs are, mostly, unobserved but applying contest theory and assumptions about the behavior of the rent-seekers, the size of the social cost can be inferred from the value of the contestable rents. ${ }^{13}$

The rent-seeking behavior on Indonesia's extractive industry is not something surprising. At least there are two vulnerable processes to the practice of rent-seeking; during the tender and sharing. During the tender process, there are two different mechanisms applicable for the petroleum sector (oil and gas) and the mining sector. Indonesia awards petroleum licenses through a competitive process usually held

12 J.M.Mbaku, Corruption and Rent-Seeking (London: Palgrave Macmillan, 1998), p.192-195.

13 T. S. Aidt, "Rent-seeking and the Economics of Corruption," Constitutional Political Economy, Vol. 27 No. 2, June 2016, p.143. 
twice a year. The Special Taskforce for Upstream Oil and Gas Business (SKK Migas) undertakes the function in granting the oil and gas licenses to contractors, while the tender process is carried out by the Directorate General of Oil and Gas, Ministry of Energy and Mineral Resources (MEMR). The government publishes the information after negotiation including the result of the auction rounds such as bids received and winning bids. However the final contracts including the geological and geographical information are not disclosed. The companies conduct the survey of geological and geophysical by their own expense and risk. The data would be submitted to the MEMR but it remains confidential until the company relinquishes the work area production has been terminated. ${ }^{14}$

While in mining, the law actually requires the open-bidding process, licenses are in practice awarded through the "first-come, firstserved basis". The central government awards the licenses for mining areas of more than 12,500 acres. The licenses below of the 12,500 acres are undertaken by the province and district governments. Even though in September 2014 the parliament passed the Laws no.23 of 2014 concerning of the Regional Government, which emphasizes that the provincial governments are having rights in granting licenses rather than the district governments, the law is inconsistent with the existing mining law where district governments also have the authority. ${ }^{15}$ According to the data of Directorate General of Mineral and Coal, by 2017 there were 2,198 licenses from the total of 8,588 licenses considered as "non-clean and clear" or do not follow the proper licensing mechanism resulting in overlapping licenses. ${ }^{16}$ The central and regional governments only disclose the bidding winner without any geographical and geological information that trigger the contestation among contractors.

The non-transparent processes both in petroleum and mining tender are the loopholes for the existence of many rent-seeker including actors in government, politicians, and businessmen. Most of the time, the rent-seekers play in the safe zone, where they are able to utilize the regulations for their benefit. The cases still happened

14 Natural Resource Governance Institute, Indonesia (Country Strategy Note) Jakarta: Natural Resource Governance Institute, 2015), p.4.

15 Ibid., p.5.

16 Directorate General of Mineral and Coal, MEMR, Achievement of Sub Sector Mineral and Coal 2017 and Outlook 2018 (Jakarta: MEMR, 2017), p.3. 
during the licenses granting in regional level, even the case in the central government still massively happen.

Rubi Rubiandini, the former director of SKK Migas, was sentenced seven years in prison and fined USD 14,500 because he accepted the bribe of USD 900,000 from elites in SKK Migas and USD 180,000 from Widodo Ratanachaithong, CEO of Kernel Oil Pte, regarding the regulations on limited auctions of crude oil and condensate. During his trial, it is known the idiom of "open the drums" means the bribe from SKK Migas to MEMR and "close the drums" means the bribe to Commission VII of House of Representative (covering the issue of energy and mineral resources). ${ }^{17}$

The rent-seeking during the tender with the non-disclosure of geological and geographical aspect might be the vulnerability for the following processes, especially when the contractors should report or share its production contribution to the state. Here the relations of rent-seeking to the illicit financial flows are so close, not only defined as the bribery itself but also the share-avoidance. The Laws no.22 of 2001 concerning of the Oil and Gas did not set a limit of cost recovery as the part of the Production Sharing Contract (PSC) mechanism. As a consequence, the cost of courting the elites began to be included into the "cost-recovery". ${ }^{18}$ The next section will further explain about how the illicit financial flows happen due to the data flow problems of the Production Sharing Contract (PSC) mechanism, which includes the scheme of "cost-recovery" that is now changed to the "gross-split" scheme since the release of the Regulation of Minister of Energy and Mineral Resources no. 8 of $2017 .{ }^{19}$

The second nature of why Indonesia's extractive industries are prone to the illicit financial flows is the dynamics of the commodity prices. Extractive industries are highly dependent to the world commodity prices, the share to the government is also dependent. When the price is high, the share is relatively high meanwhile when the price is low, the share is relatively low. The illicit financial flows

17 Asmiati Malik, "Why Indonesia's Energy Sector is so Corrupt" The Diplomat, (https://thediplomat.com/2018/o4/why-indonesias-energy-sector-is-socorrupt/, accessed on July 17, 2018).

18 Ibid.

19 A. Lukito - T. Watson, "Gross-split PSCs - a spur for investment?", Indonesia Energy, Utilities, \& Mining News Flash, No.6o, February 2017, p.1. 
could be bigger during the peak of price to maximize the profit of extractive industries by doing the trade mispricing and invoicing. ${ }^{20}$

In Indonesia's case, referring to the statement of Sri Mulyani as the Minister of Finace that even when the country reached its peak price of extractive commodity or so called as price-booming since 2010, the obedience of taxpayers remained unaffected in this sector. In 2011, there were 3,037 obedient taxpayers from the mining industry, with the rest of 2,964 as offenders. In 2012, there were 3,081 obedient taxpayers with 2,920 offenders. But in 2013 the number of offenders was even increasing to the 3,035 , with the rest of 2,966 as obedient taxpayers. The number was growing until 2014 with the total of 3,160 offenders and 2,841 obedient taxpayers. ${ }^{21}$

\section{Scrutinizing The Sources Of Indonesia Extractive Industries To Illicit Financial Flows}

There are basically two sources in looking and measuring illicit financial flows, which are trade misinvoicing and hot money narrow. Trade misinvoicing is a method for moving money illicitly across borders which involves the deliberate falsification of the value or volume of an international commercial transaction of goods or services by at least one party to the transaction..$^{22}$ On the other hand, hot money narrow is the leakages from the balance of payments which indicate unaccountable outflow. Trade misinvoicing is considered to be the prominent source of illicit financial flows. ${ }^{23}$ Illicit financial flows in Indonesia mining sector is also dominated by trade misinvoicing cases which reached IDR 21.33 trillion in 2014. ${ }^{24}$ In this regard, tax avoidance such as Base Erosion and Profit Shifting (BEPS) is one of the primary motivations to conduct the illicit practice. BEPS basically

20 Y. S. Adi, Thesis: "The Influence of Extractive Industry Transparency Initiative (EITI) on Countries Compliance: The Case of Indonesia" (Yogyakarta:

Universitas Gadjah Mada, 2017), p.37.

21 Fiki Ariyanti, $\square 31$ Perusahaan Tambang Mangkir Lapor Data Pajak, Ini Daftarnya! $\square$ Liputan 6, (http://bisnis.liputan6.com/read/2372772/31perusahaan-tambang-mangkir-lapor-data-pajak-ini-daftarnya, accessed on May 31 2017).

22 Global Financial Integrity, “Trade Misinvoicing”, (http://www.gfintegrity.org/ issue/trade-misinvoicing/, accessed on 12 July 2018).

23 Trade misoinvincing in general could also include specifics methods of moving money illicitly, such as trade-based money laundering.

24 Saputra - Abdullah, Op.cit., p.2. 
refers to tax avoidance strategies that exploit gaps and mismatches in tax rules to artificially shift profits to low or no-tax locations. ${ }^{25}$ Therefore, it is important to look at the mechanism of extractive sector and the laws and regulation that governs in order to analyze the sources of the vulnerability.

There are three main sources of regulatory vulnerability that directly and indirectly influence illicit behavior, which are the different sets of revenue data, arm's length measurement within the vulnerable enforcement, and regarding the cost recovery scheme. First, the problem can be found by looking into the data collection, data flow, and taxation mechanism. The government's take from extractive sectors are derived from the share within the production sharing contract, bonuses, royalties, and tax payment. There are different sets of data found between government agency and institutions concerned in terms of tax and revenue. For example, in 2017, the data from Center for Statistical Agency (BPS) stated that the overall natural resource non-tax revenue amounted for IDR 95.643 billion. ${ }^{26}$ On the other hand, the performance report published by the Directorate General of Oil and Gas stated that the sector's non-tax revenue amounted for IDR 88.556 billion, ${ }^{27}$ while the report from the Directorate General of Mining and Coal stated that the sector's nontax revenue amounted for IDR 40.62 trillion, ${ }^{28}$ which in total would generate a different calculation. The data from Central Government Financial Statement (LKPP) on the same year also shows difference with oil and gas revenue amounted around IDR 81 trillion and mineral revenue amounted around IDR 24 trillion. ${ }^{29}$ The details on data differences throughout 2015-2017 can be seen from Table 1.

25 OECD, "Base Erosion and Profit Shifting”, (http://www.oecd.org/tax/beps/, accessed on 12 July 2018).

26 Center for Statistical Agency, "Realisasi Penerimaan Negara” BPS, (https:// www.bps.go.id/statictable/2009/02/24/1286/realisasi-penerimaan-negaramilyar-rupiah-2007-2017.html, accessed on 15 July 2018).

27 Directorate General of Oil and Gas, 2018, Laporan Kinerja, The Ministry of Energy and Mineral Resources, Jakarta.

28 Directorate General of Mineral and Coal, 2018, Laporan Kinerja, The Ministry of Energy and Mineral Resources, Jakarta.

29 Central Government, 2018, LKPP Tahun 2017, The Ministry of Finance, Jakarta. 
Table 1 Data Report on Non-Tax Revenue from Natural Resources 2015-2017 (in IDR Trillion) $)^{30}$

\begin{tabular}{l|r|r|r}
\hline \multicolumn{3}{c}{ SOURCES } & \multicolumn{3}{c}{ YEAR } \\
\cline { 2 - 4 } & \multicolumn{1}{c}{$\mathbf{2 0 1 5}$} & $\mathbf{2 0 1 6}$ & \multicolumn{1}{c}{$\mathbf{2 0 1 7}$} \\
\hline Natural Resources & 100,971 & 64,901 & 95,643 \\
\hline BPS (Natural Resources) & 112,363 & 89,704 & 135,324 \\
\hline LKPP (Natural Resources) & 95,853 & 59,850 & 105,606 \\
\hline Extractive Sectors & 115,74 & 99,324 & 129,176 \\
\hline LKPP (Oil, Gas, and General Mining)
\end{tabular}

SOURCE: COMPILED BY AUTHOR

In this regard, it can be argued that as vulnerabilities are correlated with risks and actual loss, the data issue is correlated with the risk of giving room for data manipulation, the loss of tax revenue, and capital flight. The room for data manipulation can also be understood as the underlying mechanism in which trade misinvoicing conducted. It is stated that the differences found between the Ministry of Trade, Ministry of Energy and Mineral Resources, and the Directorate General of Customs Ministry of Finance data make it difficult to enforce law and regulation. ${ }^{31}$

The lack of the unified data calculation also produced risk in regard to the new gross split scheme which depends on the measurement of gross revenue in order to calculate the value of the split percentage. The production sharing contract (PSC) scheme is recently generated in order to promote investment in the oil and gas sectors after the implemented cost recovery scheme. In the gross split scheme, the contractors should bear the operational costs of exploration and exploitation - contrasts with the reimbursement scheme in cost recovery - but would have bigger anchoring share of base split. The base split in the oil sector is $57 \%-43 \%$ and in the gas sector is $52 \%$ $48 \%$ for the government and contractor respectively. ${ }^{32}$ If combined

30 Natural resources data includes revenue from fisheries, forestry, and other natural resources. The mismatch is not only in the total excluding the other natural resources except oil, gas, mining, and coal, but also in each sector compared to the performance report.

31 Anugerah Perkasa, “DJP Akui 'Kekacauan' Data Pajak Pertambangan Minerba” CNN Indonesia, (https://www.cnnindonesia.com/ekono mi/20170124173657-85-188620/dpr-dan-kkks-tetap-pilih-cost-recoveryketimbang-gross-split, accessed on 15 July 2018).

32 The Regulation of the Minister of Energy and Mineral Resources number 18/2017, Gross Split Production Sharing Contract, 17 February 2017, Official 
with weak monitoring regulation and enforcement, there is a risk of misinvoicing and other related manipulation scheme within the measurement of the value of the decided percentage, thus leading to further difficulties of taxation measurement validity.

Second, the arm's length measurement is crucial to the transfer pricing between related onshore and offshore companies which is closely related to taxation of transaction and profits. Indonesia's adoption of this measurement can be mainly seen in the regulations regarding the general provision, documentation, and implementation, which are in Article 18 of the Income Tax Law 36/2008 as the fourth revision of the Income Tax Law 7/1983, Government Regulation 80/2007, Regulation of the Tax General Director PER-32/PJ/2011 as the revision of PER-43/PJ/2010, and Regulation of the Ministry of Finance No. 213/PMK.03/2016. In general, arm's length measurement is a method of valuing transactions within MNEs at the prices that would have been agreed by unrelated parties. ${ }^{33}$ Therefore, arm's length measurement is a way to regulate transfer pricing between related parties, such as between parent and subsidiary companies, as if it were between unrelated parties to ensure that there are no special treatment in terms of determining the transaction value.

As Indonesia's tax system is mainly self-assessment and reporting in terms of burden of proof, the main problem in implementing the arm's length measurement is in the government capability to measure the actual value of the transaction. Fair transfer can be regarded as inherently problematic when we look at the underlying mechanism of the influence of the negotiation process. In a normal market interaction, two independent, self-interested parties work together to negotiate a fair price, but when a transaction occurs between two connected parties, as in transfer pricing, the fair price must be designated, rather than decided by the market. ${ }^{34}$ Contractors in extractive sectors, especially the mineral sector, have been known to have subsidiaries and other related companies outside of the jurisdiction - offshore companies - of its exploration and exploitation

State Gazette of The Republic of Indonesia 2017 Number 303, Jakarta.

33 Michael Keen - Peter Mullins, International Corporate Taxation and the Extractive Industries: Principles, Practice, Problems, Philip Daniel et al (Eds.), (New York, NY: Routledge, 2017), p.13.

34 Julia Van Hoogstraten, Theoretical Framework for Financial Flows in the Extractive Sector, (New York: PODER, 2015), p.25. 
place as a part of its value chain. As most of its products are exported in an intragroup context, the price calculation is a problem of information for the government due to the government's - or external actors of the companies doing the transaction - inability to have full detail of the valuation process; from the calculation of verifying the reference prices, assets used, operational costs, and risks. IMF also stated that the issue of measuring profitability based on the arm's length principle is seriously flawed in the mining sector due to its frequent engagement in a vertically integrated structure. ${ }^{35}$

The difficulty can be further emphasized in the sense that the process of the valuation of such comparable prices may simply not exist so that arriving at a valuation will depend very heavily on the facts and circumstances of each case and require some degree of judgment, with the MNE potentially enjoying advantages of having better information than the tax authorities, for instance on the potential value of an intangible it has developed or a resource deposit it has found ${ }^{36}$ Contractors are able to further exploit gap in a high volatility prices context. As stated in the previous section, contractors may seek to maximize its profit by shifting the intragroup transaction invoice during the peak price. In this regard, the decline of world commodity prices that extractive commodities mostly depend does not necessarily mean that there are less possibilities of this rentseeking behavior; in contrasts, contractors still try to maximize profits when prices are low.

It does not mean - while true to some extend - that the arm's length measurement is a flawed measurement in itself. The arm's length principle was generated from the lack of framework and foundation in regard to regulating transparency and fairness within intra group transaction or transactions between companies with special relationship. It should be emphasized in its intertwining aspect with the need for heavy - but fair - regulation and enforcement and the ability to collect and analyze data or information. In this regard, Indonesia still has a weakness in its scrutinizing capabilities on collecting and analyzing necessary information, such as to generate reference prices and to validate which need an open and integrated data flow that are regulated and enforced accordingly. Especially

35 International Monetary Fund, 2011, Supporting the Development of More Effective Tax Systems, IMF, 4.

36 Keen - Mullins, Op cit., p.14. 
in the extractive sectors where there are more complex regulations entangled within the tax system between the income, royalty, and special treatment aspects. Therefore, it can be argued that the vulnerability in this context is a gap between government's access to information and contractors that can be exploited in loose or flawed monitoring, regulation, and law enforcement.

Third, the cost recovery scheme is unique to oil and gas sectors and regulated in the Government Regulations No. 79/2010. The cost recovery scheme as a PSC regulates theoperational cost reimbursement from production results of the costs incurred by the contractors in conducting exploration, exploitation, and other permitted expenses. ${ }^{37}$ As a consequence, majority of the revenue generated within the sharing mechanism are given to given the government, which divided between 85:15 for petroleum and 70:30 for gas but subject to adjustment especially during peak prices. The cost recovery then, is paid in the form of oil and gas production which valued by Weighted Average Price, which is the average of value traded based on the lifting value over a year period divided with the lifting amount of units over the same period..$^{8}$ While the scheme is now replaced by gross split that had been introduced by the government, the already active contractors could still chose between the two PSC schemes. Thus, the cost recovery scheme is still in its transition period. In this regard, the scheme and transition are problematic due to two main points, which are in its practicality and rough transition.

During its implementation, there are cases of cost recovery in which the contractors exploit the costs incurred and not generating profits for the government in terms of its results. Up until 2018, there are still problems found within the scheme implementation when the Audit Board of the Republic of Indonesia (BPK) discovered four blocks of oil and gas non-compliant to the regulation. ${ }^{39}$ Even though the Government Regulation No. 79/2010 already covered the categories of reimbursed costs, monitoring scheme, and auditing,

37 EITI, 2015, EITI Indonesia Report: Contextual Report, EITI, Jakarta, p.6.

38 Abdul Nasir, Sejarah Sistem Fiskal Migas Indonesia (Jakarta: Grasindo, 2014), p.78.

39 Anggita Rezki Amelia, "BPK Temukan Cost Recovery Empat Blok Migas tak Sesuai Aturan”, Katadata, (https://katadata.co.id/berita/2018/04/o3/bpktemukan-cost-recovery-empat-blok-migas-tak-sesuai-aturan, accessed on 15 July 2018). 
the cost recovery scheme is in itself have much more difficulties to be implemented, hencebecame a problem of practicality. The government has to address all the incurred costs which between contractors can be different due to the influence of technology used, technical mechanism implemented, and other variations of costs calculation. In pursuing of validating costs reimbursement, the government can be contradicted between the essence of cost recovery in attracting investment and maximizing revenue due to the practicality problem of validating the actual costs. Therefore, it is often found that there are cost mark ups by contractors by including negative list cost recovery, ${ }^{40}$ as stated by Tullock (2005) about how the size of the social cost can be inferred from the value of the contestable rents. The vulnerability related to rent-seeking behavior accommodated in this context can be argued as the problematic practicability of inferring actual costs within the lack of strong regulation and enforcement.

Along with the current regulation and system in the central government which may become the loopholes of the practice of illicit financial flows as explained previously, the multi-level governance context also plays its role to the vulnerability of Indonesia's extractive industry to the illicit financial flows. Since 2001, the release of decentralization policy gives the discretionary authority to the local governments to manage the natural resources including some of the extractive industries. It also gives the authority to devise their own economic strategy, especially to increase the revenue, formulate local spending budget and make local spatial plans. By this policy, the involvement of the local actor becomes stronger.

In extractive industry, as explained by the previous chapter that actually the role of licensing in mining industry is divided into the responsibility of the central government and local governments. The stipulation of Laws no.23 of 2014 concerning of the Local Government which grant the authority for the provincial governments even though contribute to the increment of the "Clean and Clear $(\mathrm{CnC})$ " mining licenses but it does not directly solve the issue of the mining licensing. 
Table 2 Clean and Clear Mining Data ${ }^{41}$

\begin{tabular}{l|r|r|r}
\hline \multicolumn{1}{c|}{ YEAR } & CNC & TOTAL LICENSES & $\%$ \\
\hline 2014 & 6,000 & 10,643 & $56 \%$ \\
\hline 2015 & 6,370 & 10,339 & $62 \%$ \\
\hline 2016 & 6,202 & 9,370 & $66 \%$ \\
\hline 2017 & 6,390 & 8,588 & $74 \%$ \\
\hline
\end{tabular}

SOURCE: COMPILED BY AUTHOR

The data strengthened the argument that the release of Law no.23 of 2014 is the form of the central government awareness that the mining licensing authority is actually contestable among government levels. Under the decentralization, national government's authority in managing natural resources has been increasingly challenged by the local actors. It might also cause the trust issue among the government levels. Here the decision to strengthen the role of provincial governments shows the urgency of the central government to tighten the control over the mining licensing.

According to the McCharty, the decentralization policy has provided more opportunity not only to raise the revenue for the local governments but generate the rent-seeking for the local actors..$^{42}$ By also looking at the authority level which might be contested each other in granting the license of mining industry, but the problems also lie on the more number of rent-seekers that might work in central, provincial, and/or district level.

Natural resources policies are now also contested and redefined by these actors not only through the institutional intervention but also discourse and norms under the logic of multi-level governance - a process which refers to negotiated, non-hierarchical exchanges between institutions at the transnational, national, regional and local levels and to a vertical 'layering' of governance processes at these different levels. ${ }^{43}$

In regards to the practice of the illicit financial flows, the relations of rent-seeking to the methods of illicit financial flows are really

41 Directorate General of Mineral and Coal, MEMR, Achievement of Sub Sector Mineral and Coal 2017 and Outlook 2018 (Jakarta: MEMR, 2017), p. 3.

42 J. F. McCharty, "Changing to Gray: Decentralization and the Emergence of Volatile Socio-Legal Configurations in Central Kalimantan, Indonesia,” World Development, Vol.32, No.7, 1206.

43 I. Bache - M. Flinders, Multi-level Governance (New York: Oxford University, 2005), p. 131. 
close. As explained earlier that the non-transparent practice during the licensing process of the extractive industry will also trigger the avoidance during the sharing process between the host-government and the industry. In this sense, the local government might not have the capacity to accurately measure the potential revenue coming from the extractive industry. Furthermore, the implementation of decentralization will lead to the broader undetected illicit flows since the domain of the share is divided into the central and local authority.

A case from Bojonegoro happened in 2015. The local government projected the annual revenue from the extractive industries profit share would be around IDR 900 billion, meanwhile during the share, they only received the actual amount of IDR 700 billion. As the consequence of the inaccurate local budget (APBD) arrangement, they had to proceed the loan of IDR 100 billion. The additional interest was applicable by the lender to this loan. The local government of Bojonegoro had questioned this case to the central government. The reduction to the profit share might be applicable but not transparently shared by the central government, meanwhile the local governments do not have the capacity the conduct the accurate measurement. Bambang Raflis from the Directorate General of Financial Balance stated that his Directorate is ready to share the data principle; however there are some of the data of non-tax revenue and the reduction factors from the Directorate General of Budget. In another case, the provincial government of Riau, especially from the Energy and Mineral Resources Department questioned on the flows of revenue tax (PPh 21) payment from the extractive companies in Riau which currently only being paid to the region where the headquarter of the company located. Meanwhile the tax-payers, which are the workers, might be working in their region. Riau's government considered that the Profit Sharing (DBH) from the central government should be adjusted, and tax revenue could be one of the indicators. 44

From these two cases we can see the relations of the multi-level governance context to the practice of illicit financial flows. It can be argued that the current multi-level governance system is lacking over the coordination shown by the misunderstanding upon some of the issues, such as the central-local sharing. In another case, the

44 EITI Indonesia, "Pentingnya Transparansi Dana Bagi Hasil (DBH) untuk Daerah”, (http://eiti.ekon.go.id/pentingnya-transparansi-dana-bagi-hasil-dbhuntuk-daerah/, accessed on 21 July 2018). 
central government also realizes that actually the current system of coordination will lead to lack of the control. The enactment of Law No.23/2014 shows the urgency to limit the authority of the district governments and put more power for the provincial governments; which would be easier to be controlled by the central government. The problems of ego-sectorals are also shown by the problem of data management among the government agencies. The discrepancy on the government datas might also ease the falsification by the industry as stated previously that the concerning government bodies found it difficult to enforce law and regulation.

It can be concluded that the trust issues among the government levels and agencies become a loopholes for the practice of illicit financial flows. The practice of misinvoicing and the leakage of BOP would be easier to be executed by the industry or specifically the rentseekers as the misunderstanding and the miscoordination among the departments and government levels are happening. In a more advance way, the differences of the data between government levels might be utilized by the rent-seekers to bring the central and local governments into conflict since the understanding of both levels might be different in technical aspects of the profit sharing.

\section{CONCLUSION AND RECOMMENDATION}

Indonesia's extractive industry is prone to the illicit financial flows because of the governance-which directlyand indirectlyaccommodate the rent-seeking and influence the illicit financial flows. There are at least three main sources of regulatory vulnerability, which are the different sets of revenue data, arm's length measurement within the vulnerable enforcement, and regarding the cost-recovery scheme. All these three sources of vulnerabilities, the access of information and lack of integrated and assertive government regulation are found to be the prominent technical problems of the gaps and risks to illicit financial flows. Other than that, the multi-level governance context shown by the decentralization of natural resources also creates the loopholes to the illicit financial flows. The trust issues, misunderstanding and the mis-coordination among the departments and government levels ease the practice of falsification that leads to the illicit financial flows.

The gaps and risks within the extractive industries in Indonesia should be responded with internal and external practices of reform. 
Internally, there are at least two ways of addressing the vulnerabilities of extractive sectors, which are implementing assertive regulation of data collection, data flow and databases between concerning institutions and innovating on ways of surfacing actual values.

First, Indonesia needs a more robust data regulation concerning taxes in extractive industries which are collected under an integrated methodology and mechanism, then circulated within an open and integrated platform. This task should be done by the Directorate General of Taxation under the Ministry of Finance. Indonesia actually has a regulation regarding the data transfer concerning taxes in the Indonesia Law 28/2007 article 35 about Tax General Provision and Procedures. Furthermore, the Government Law 31/2012 about Tax Data and Information Collection and Transfer already regulated the general mechanism in which data are flown between concerning parties. Nonetheless, it can be seen that the data problem still persists. In this regard, the data regulation should also the address the importance of having similar methodology and assessment, especially regarding value calculation concerning taxes and profit sharing in the extractive sectors. This is also important politically to uphold the government's bargaining position by having the same data between department and institution. It is urgent for the concerning parties to build an integrated big database that are accessible in order to promote transparency. The loss of not having a comprehensive data regulation concerning data collection, data transfer, and databases can also be seen in the case of Bojonegoro in 2015 as described in the previous section where the local government had to endure the loss of miscalculation related to the lack of access to proper data and information.

Second, ways of surfacing actual values can be done through bidding and benchmarking. Innovating on ways to reveal actual values from the side of the contractors are crucial due to the underlying mechanism of reporting in this context is still self-reporting. It should also be contextualized within the phases on spotlight, such as the bidding that can be focused more on the licensing phase and benchmarking on the reporting and validating. The practice of bidding in order to get licenses is a significant step to influence the tendency of rent-seeking behavior in the area of natural resources. Bidding can provide a main function of helping government to see the actual values of certain areas or aspects that are often hard to be 
measured, such as the actual value of land conversion for mining. It is also argued by Collier that in the natural resources sectors where licenses are often the place where illicit financial flows started, having an auction is a way of forcing companies to reveal the true value of a right to extract by placing them in a competition. ${ }^{45}$

The practice of benchmarking is also essential as can be seen by the findings that it is virtually impossible for the government to access full information needed to calculate the actual value of certain transactions and profits. Benchmarking can serves as an anchor that is crucial to the process of negotiation and validation which can also be seen as a reference price to certain methods of cost calculation. As the mechanism of transactions often related to offshore parties, benchmarking can be done by having or including it in a Governmentto-Government (G2G) agreement or partnership.

Externally, there are two ways for the Indonesian government to tackle the issue with the assistance of external forces. The first one is by conducting the G2G bilateral partnership on illicit financial flows and the second is by its membership on EITI.

As the illicit financial flows are closely related to the existence of tax havens countries, the bilateral relations especially in terms of the benchmark data sharing might help the government to validate the existence of the illicit financial flows. This initiative has been executed by the African, Carribean, and Pacific Group of States (ACP) by engaging the European Union (EU) to combat the illicit financial flows in bilateral manner. The resolution has been agreed during the meeting in Nairobi on December 19th to 21st 2016. There are 24 points on the resolution consist of the recommendation and assistance on the technical and financial. The recommendation consist of the suggestion to make use of the OECD tax model, the membership to EITI, to recall the tax-havens to work together under the name of the development, and the legal obligation covering all of the mineral supply chain. The assistance consist of the financial and technical assistance on regulatory framework, tax administration, and institutional development. The resolution also shows the commitment of EU to have the automatic exchange of the data, meanwhile the ACP also commit to share the state and local authority budget as part of the assistance program. ${ }^{46}$

45 P. Collier, "The Political Economy of Natural Resources”, Social Research, Vol 77 No 4, 2010, 1128.

46 ACP-EU, “ACP-EU Joint Parliament Assembly Resolution”, (http://www. 
The second initiative is by actively involving to the regime of EITI. EITI is the global standard for the good governance of oil, gas, and mining. EITI aims to promote the transparency among the industry and the host-government by matching the revenue earned by the government and the contribution from the extractive industries. Since September 14th 2010, Indonesian government has committed to implement the EITI standards on our extractive industry governance. By the end of 2013, the EITI Boards declared Indonesia as a candidate with "meaningful progress". Due to the size of the extractive industries and complexity of issues in Indonesia, considerable progress has been achieved since commencing the initiative. The significant progress was already sustained by the EITI stakeholders which resulted to the compliance of Indonesia by 15 October 2014. ${ }^{47}$ By the involvement to the EITI, it would improve the bargaining position of the government towards the industry, and simultaneously would help the government in validating the contribution of the extractive industry by implementing the regime standard.

\section{REFERENCES}

ACP-EU. ACP-EU Joint Parliament Assembly Resolution. http:// www.europarl.europa.eu/intcoop/acp/2016_nairobi/ pdf/10206oen.pdf. 23 July 2018.

Adi, Y. S. 2017. The Influence of Extractive Industry Transparency Initiative (EITI) on Countries Compliance: The Case of Indonesia. Thesis. Program S1 Ilmu Hubungan Internasional Universitas Gadjah Mada. Yogyakarta.

Aidt, T. S. 2016. Rent-seeking and the Economics of Corruption. Constitutional Political Economy 27(2): 142-157.

Amelia, A. R. 2018. BPK Temukan Cost Recovery Empat Blok Migas tak Sesuai Aturan. Katadata. https://katadata.co.id/ berita/2018/o4/o3/bpk-temukan-cost-recovery-empat-blokmigas-tak-sesuai-aturan. 15 July 2018.

Ariyanti, F. 2015. 31 Perusahaan Tambang Mangkir Lapor Data Pajak, Ini Daftarnya!. Liputan 6. http://bisnis.liputan6.com/

europarl.europa.eu/intcoop/acp/2016_nairobi/pdf/10206oen.pdf, accessed on 23 July 2018).

47 Adi, Loc. cit, p. 22. 
read/2372772/31-perusahaan-tambang-mangkir-lapor-datapajak-ini-daftarnya. 31 May 2017.

Bache, I. - Flinders, M. 2005. Multi-level Governance. Oxford University. New York.

Bullough, O. 2018. The Dark Side of Globalization, Journal of Democracy 29(1): 25-38.

Center for Statistical Agency. 2018. Realisasi Penerimaan Negara. https://www.bps.go.id/statictable/20o9/o2/24/1286/realisasipenerimaan-negara-milyar-rupiah-2007-2017.html. 15 July 2018.

Central Government. 2018. LKPP Tahun 2017. The Ministry of Finance. Jakarta

Collier, P. 2010. The Political Economy of Natural Resources. Social Research 77(4): 1105-1132.

Directorate General of Mineral and Coal. 2018. Laporan Kinerja. The Ministry of Energy and Mineral Resources. Jakarta.

Directorate General of Mineral and Coal. 2017. Achievement of Sub Sector Mineral and Coal 2017 and Outlook 2018. The Ministry of Energy and Mineral Resources. Jakarta.

Directorate General of Oil and Gas. 2018. Laporan Kinerja. The Ministry of Energy and Mineral Resources. Jakarta.

EITI Indonesia. Pentingnya Transparansi Dana Bagi Hasil (DBH) untuk Daerah. http://eiti.ekon.go.id/pentingnya-transparansidana-bagi-hasil-dbh-untuk-daerah/. 21 July 2018.

EITI. 2015. EITI Indonesia Report: Contextual Report. EITI. Jakarta.

Global Financial Integrity. Trade Misinvoicing. http://www. gfintegrity.org/issue/trade-misinvoicing/. 12 July 2018.

Hoogstraten, J. V. 2015. Theoretical Framework for Financial Flows in the Extractive Sector. PODER. New York.

Ilyas, F., Primayogha, E., and Wasef, M. Tata Kelola Batubara Belum Maksimal, Kerugian Negara Diindikasikan Capai 133.6 Triliun Rupiah Pemerintah RI dan KPK Mesti Beri Perhatian Serius. Indonesia Corruption Watch. https://www.antikorupsi.org/ id/kajian/tata-kelola-batubara-belum-maksimal-kerugiannegara-dïndikasikan-capai-1336-triliun-rupiah. 15 July 2018.

International Monetary Fund. 2011. Supporting the Development of More Effective Tax Systems. IMF. 
Kar, D. - Spanjers, J. 2015. Illicit Financial Flows to and from Developing Countries: 2004-2013. Global Financial Integrity. Washington, DC.

Keen, M. - Mullins, P. 2017. International Corporate Taxation and the Extractive Industries: Principles, Practice, Problems. Philip Daniel et al (Eds.). Routledge. New York.

Le Billon, P. 2011. Extractive Sectors and Illicit Financial Flows: What Role for Revenue Governance Initiatives?. U4 Issue. No. 13.

Lukito. A. - Watson, T. 2017. Gross-split PSCs - a spur for investment?. Indonesia Energy, Utilities, \& Mining News Flash. No.6o.

Malik, A. 2018. Why Indonesia's Energy Sector is so Corrupt. The Diplomat. https://thediplomat.com/2018/o4/why-indonesiasenergy-sector-is-so-corrupt/. July 17, 2018.

Mbaku, J. M. 1998. Corruption and Rent-Seeking. Palgrave Macmillan. London.

McCharty, J. F. Changing to Gray: Decentralization and the Emergence of Volatile Socio-Legal Configurations in Central Kalimantan, Indonesia. World Development 32(7): 1199-1223.

Nasir, A. 2014. Sejarah Sistem Fiskal Migas Indonesia. Grasindo. Jakarta.

Natural Resource Governance Institute. 2015. Indonesia (Country Strategy Note). Natural Resource Governance Institute. Jakarta.

OECD. Base Erosion and Profit Shifting. http://www.oecd.org/tax/ beps/. 12 July 2018.

Perkasa, A. 2017. DJP Akui 'Kekacauan' Data Pajak Pertambangan Minerba. CNN Indonesia. https://www.cnnindonesia.com/ek onomi/20170124173657-85-188620/dpr-dan-kkks-tetap-pilihcost-recovery-ketimbang-gross-split. 15 July 2018.

Prabantoro, AM. P. 2014. Migas The Untold Story. Gramedia. Jakarta.

Prakarsa. 2016. Calculating Illicit Financial Flows to and from Indonesia: a Trade Data Analysis, 2001-2014. Perkumpulan Prakarsa. Jakarta.

Saputra, W. - Abdullah, M. 2015. Illicit Financial Flows and Tax Crime in Mining Sector. Brief Note. Publish What You Pay Indonesia. Jakarta.

Salomon, M. - Spanjers, J. 2017. Illicit Financial Flows to and from 
Developing Countries: 2005-2014. Global Financial Integrity. Washington, DC.

The Regulation of the Minister of Energy and Mineral Resources number 18/2017, Gross Split Production Sharing Contract, 17 February 2017, Official State Gazette of The Republic of Indonesia 2017 Number 303, Jakarta.

Tullock, G. The Rent Seeking Society. Liberty Fund. Indianapolis.

Williams, A. 2011. Shining a Light on the Resource Curse: An Empirical Analysis of the Relationship between Natural Resources, Transparency, and Economic Growth. World Development 39(4): 490-505.

Zucman, G. 2015. The Hidden Wealth of Nations: The Scourge of Tax Havens. The University of Chicago Press. Chicago. 